\title{
Primeiro relato de Cercospora acalyphae como agente etiológico de mancha foliar em Acalypha wilkesiana no Brasil
}

\author{
Reginaldo G. Mafia, Acelino C. Alfenas \& José Renato P. Cavallazzi \\ Departamento de Fitopatologia, Universidade Federal de Viçosa, CEP 36570-000, \\ Viçosa, MG, e-mail: aalfenas@ufv.br
}

(Aceito para publicação em 23/06/05)

Autor para correspondência: Acelino Couto Alfenas

\begin{abstract}
First record of Cercospora acalyphae as the etiological agent of Acalypha wilkesiana leaf-spot in Brazil

In July 2004, leaf-spot were observed on Acalypha wilkesiana var. Hoffmanii, growing in the gardens of the Campus of the Universidade Federal de Viçosa (state of Minas Gerais, Brazil). Fungal structures were examined and corresponded to those described for Cercospora acalyphae. This species was previously known from Brazil only attacking Acalypha marmorata in São Paulo. The fungus was isolated and pathogenicity to $A$. wilkesiana was demonstrated. This represents the first record of this host-pathogen association for Brazil.
\end{abstract}

A acalifa (Acalypha wilkesiana Müll. Arg.), Euphorbiaceae, é uma espécie nativa das ilhas do Pacífico que se tornou bastante popular no Brasil como ornamental (Lorenzi \& Souza, Plantas Ornamentais no Brasil arbustivas, herbáceas e trepadeiras. 2001). Em meados de julho de 2004, observou-se, em plantas de A. wilkesiana var. hoffmanii, cultivadas no Campus da Universidade Federal de Viçosa (UFV), a ocorrência de manchas foliares grandes, irregulares, cinzento-escuras (Figura 1A) que, ao atingirem a borda das folhas, causavam o encarquilhamento. Sobre a superfície abaxial das lesões, observou-se a presença constante de intensa esporulação esbranquiçada de um fungo, cuja morfologia correspondia ao gênero Cercospora (Crous \& Braun, Mycosphaerella and its anamorphs: Names published in Cercospora and Passalora. CBS. The Netherlands. 2003), com conidióforos escuros e simpodiais, agrupados em fascículos e com conídios evidenciando cicatrizes truncadas, escuras e espessadas (Figuras 1BD). Estas características correspondem às descritas para a espécie Cercospora acalyphae Peck, anteriormente relatada em São Paulo, para outra espécie de acalifa (Hino \& Tokeshi, Some pathogens of cercosporiosis collected in Brazil. Tropical Agriculture Research Center, Ministry of Agriculture, Forestry and Fisheries. Tóquio. 1978). A partir das lesões foliares, obtiveram-se culturas puras do fungo. Para comprovação da patogenicidade, realizaram-se inoculações artificiais em plantas sadias de acalifa, pela deposição de discos de culturas do fungo em batata-dextrose-ágar (BDA) sobre as folhas. Serviram de testemunhas plantas sobre cujas folhas houve apenas a deposição de discos de BDA não colonizados pelo fungo. Após a inoculação, os ramos contendo as folhas inoculadas foram mantidos em sacos plásticos com algodão umedecido formando uma câmara úmida por $48 \mathrm{~h}$, em temperatura ambiente. Dez dias após a inoculação, observaram-se lesões necróticas somente nas folhas inoculadas com os discos de cultivo contendo o fungo. A partir das lesões resultantes, realizou-se o re-isolamento do patógeno, obtendo-se o mesmo tipo de colônia, confirmandose assim a etiologia da doença. Este é o primeiro relato desta associação patógeno-hospedeiro para o Brasil. C. acalyphae já foi relatada também na China, Cuba, Índia, Jamaica, Japão, Ilhas Salomão, Estados Unidos e Venezuela. Folhas doentes foram herborizadas e depositadas no herbário da Universidade Federal de Viçosa (VIC 28733).

Agradecimentos: agradecemos ao Prof. Robert W. Barreto (UFV) pela revisão do manuscrito.
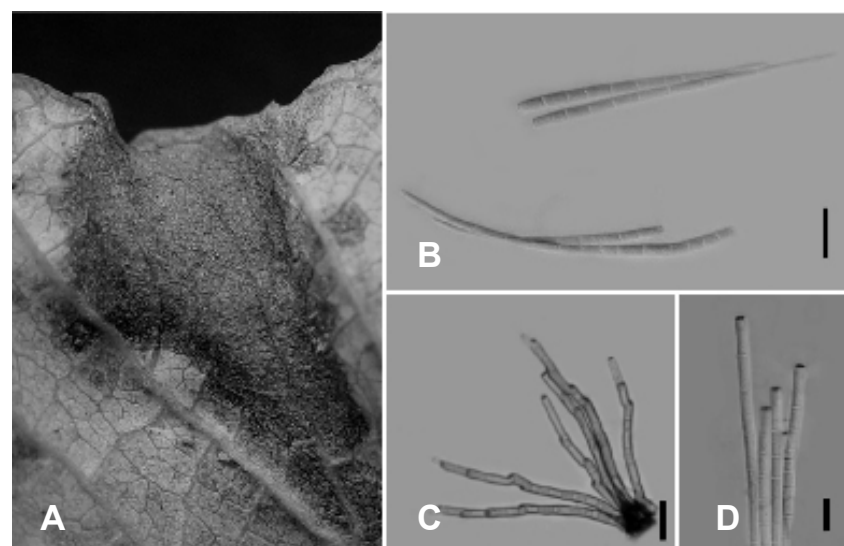

FIG. 1 - Sintomas da cercosporiose em acalifa (Acalypha wilkesiana): A. Lesões foliares grandes, irregulares e de coloração cinza escura; B. Conídios; C. Conidióforos escuros e simpodiais; e D. Porção basal de conídios mostrando cicatrizes conidiais truncadas, escuras e espessadas Barras de $10 \mu \mathrm{m}$ (B e D) e $20 \mu \mathrm{m}$ (C). 